Génét. Sél. Evol., 1985, 17 (4), 443-458

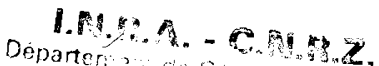

$$
\begin{aligned}
& \text { hisicinge Animale } \\
& \text { F YUJBO JOUY EN JOSAS }
\end{aligned}
$$

\title{
Coat colour inheritance in the Belgian White and Blue cattle breed
}

\author{
R. HANSET \\ Chaire de Génétique, Faculté de Médecine Vétérinaire (U.Lg) \\ 45, rue des Vétérinaires, B-1070 Bruxelles
}

\begin{abstract}
Summary
The Belgian White and Blue cattle breed exhibits of coat colour polymorphism with 3 phenotypes : all-white, blue and black. Three genetic models : 1) a single gene model without dominance ; 2) an epistatic model with 2 pairs of genes ; 3) an additive model with 2 pairs of genes - were fitted to segregation data. The models other than the single gene model are incompatible with the observations. Furthermore, the distributions of the proportions of blacks and of whites in the progeny of 137 A.I. sires (with an average of more than 200 progeny per sire) are distinctly trimodal, this observation corresponding to the 3 genotypes expected in the case of a single major locus with 2 alleles.
\end{abstract}

Key words : Belgian White and Blue breed, colour inheritance, major gene.

\section{Résumé}

L'hérédité des couleurs dans la race bovine Blanc-Bleu Belge

La race bovine Blanc-Bleu Belge présente un polymorphisme de couleur à 3 phénotypes : blanc, bleu et noir. Trois modèles génétiques : 1) modèle à une paire de gènes, sans dominance ; 2) modèle épistatique à 2 paires de gènes ; 3 ) modèle additif à 2 paires de gènes - ont été ajustés aux données de ségrégation. Les modèles autres que le modèle à une paire sont incompatibles avec les données d'observation. En outre, les distributions des pourcentages de sujets blancs et noirs dans la descendance de 137 taureaux I.A. (plus de 200 descendants par taureau) sont manifestement trimodales, la tri-modalité correspondant aux 3 génotypes attendus dans le cas d'un seul locus majeur à 2 allèles.

Mots clés : Race bovine Blanc-Bleu Belge, hérédité des couleurs, gène majeur.

\section{Introduction}

As in the Shorthorn breed, the Belgian White and Blue breed exhibits a coat colour polymorphism with 3 phenotypes : -1 . all-white with blue ears; -2 . blue ; - 3. black. Besides this, the piebald pattern, caused by the genotype ss, is the rule but is only expressed in the blues and in the blacks. 
Regarding these phenotypes, blue and black in the Belgian cattle correspond respectively to roan and red in the Shorthorn. The blue (or roan) phenotype is due to the intermingling of black (or red) hairs with white hairs. The transmission pattern is quite similar for the 2 breeds, as shown earlier (HANSET, $1959 \mathrm{a}, 1959 \mathrm{~b}, 1965$ ). Furthermore, the so-called «White Heifer Disease» (or «White Shorthorn Disease ») has been described in both breeds (RENDEL, 1952; HANSET, 1965). Historical records exist which show that breeding animals of the Shorthorn (or Durham) breed were imported into Belgium during the second half of the XIXth Century. Undoubtedly, the same genes are involved.

\section{Genetic models}

The segregation of 3 phenotypes suggests a simple genetic determinism : a pair of alleles, $R$ and $r^{+}$, the heterozygous $\left(R r^{+}\right.$, blue or roan) being intermediate between all-white $(R R)$ and black (or red) $\left(r+r^{+}\right)$. Other symbols have been proposed for this gene of dominant white : $r$ by SMITH (1925) and RENDEL (1952), $N$ by IBSEN (1933), $B d^{m}$ by LAUVERGNe (1966).

According to this simple genetic model, the different mating types, regarding the colours of the parents, are expected to give the results shown in table 1 . The observed results, taken from HANSET (1965) and concerning Herd-Book data, are given in parentheses.

\section{TABLE 1}

Expected (single gene hypothesis) and observed results from all possible mating types regarding the coat colour.

Résultats attendus (hypothèse d'un seul gène) et observés pour tous les types d'accouplement possibles concernant la couleur de la robe.

\begin{tabular}{|c|c|c|c|c|}
\hline \multirow{2}{*}{ Parents. } & \multicolumn{4}{|c|}{ Offspring } \\
\hline & White (RR) & Blue $(R r+)$ & Black $(r+r+)$ & Total numbers \\
\hline $\begin{array}{c}\text { White } \\
\times \\
\text { White }\end{array}$ & $\begin{array}{l}100 \% \\
(88.5 \%)\end{array}$ & $\begin{array}{c}- \\
(10.0 \%)\end{array}$ & $\begin{array}{c}- \\
(0.5 \%)\end{array}$ & 582 \\
\hline $\begin{array}{c}\text { White } \\
\times \\
\text { Blue }\end{array}$ & $\begin{array}{c}50 \% \\
(46.5 \%)\end{array}$ & $\left.\begin{array}{cc}50 & \% \\
(50.3 & \%\end{array}\right)$ & $\begin{array}{l}- \\
(3.2 \%)\end{array}$ & 829 \\
\hline $\begin{array}{c}\text { White } \\
\times \\
\text { Black }\end{array}$ & $\begin{array}{l}- \\
7.5 \%\end{array}$ & $\begin{array}{l}100 \% \\
(80.8 \%)\end{array}$ & $\begin{array}{c}- \\
(11.7 \%)\end{array}$ & 214 \\
\hline $\begin{array}{c}\text { Blue } \\
\times \\
\text { Blue }\end{array}$ & $\begin{array}{c}25 \% \\
(25.7 \%)\end{array}$ & $\begin{array}{l}50 \% \\
(52.14 \%)\end{array}$ & $\begin{array}{l}25 \% \\
(22.17 \%)\end{array}$ & 884 \\
\hline $\begin{array}{c}\text { Blue } \\
\times \\
\text { Black }\end{array}$ & $\begin{array}{c}- \\
(4.6 \%)\end{array}$ & $\begin{array}{cc}50 & \% \\
(49.8 \%)\end{array}$ & $\begin{array}{cc}50 \% \\
(45.6 \%)\end{array}$ & 261 \\
\hline $\begin{array}{c}\text { Black } \\
\times \\
\text { Black }\end{array}$ & $\begin{array}{c}- \\
(5.1 \%)\end{array}$ & $\begin{array}{c}- \\
(23.1 \%)\end{array}$ & $\begin{array}{l}100 \% \\
(71.8 \%)\end{array}$ & 39 \\
\hline
\end{tabular}


At first sight, the agreement between the observed and the expected results is not bad and a close fit is obtained for the mating blue $\times$ blue $\left(X_{2}^{2}=3.81, P<25\right.$ p. 100); nevertheless, phenotypes appear where they are not expected : blue from white $\times$ white, or from black $\times$ black, and so on.

The study of the inheritance of coat colour in the Shorthorn has attracted 2 great names of Biometrical Genetics : Karl Pearson and Sewall Wright.

BarRington \& PeARson (1906) were the first to become interested in the problem and regarding the exceptions mentioned above, they wrote : "Such cases may be very rare indeed but, if authentic, reduce the mendelian formula to a rough empirical statement of a statistical ratio; they are inconsistent with any theory of pure gametes »... «It would thus seem that no simple mendelian formula can possibly fit the Shorthorn case. Roughly, such a formula approaches the data in one or 2 points but the roughness appears inconsistent with a theory of mendelism being due to the purity of gametes $\gg$.

The debate was opened. While in Europe, WILSON (1908) supported the single gene hypothesis, in the U.S.A., WentworTH (1913) put forward a model with 2 interacting pairs of genes. Applied to the Belgian Blue, Wentworth's model can be written as in table 2 . The interaction of 2 dominant genes $P$ and $R$ results in the blue phenotype. In the absence of the $R$ allele, the phenotype is all white. In the absence of the $P$ allele, but the $R$ allele being present, the phenotype is black. This model is an example of recessive epistatic action (DARLINGTON \& MATHER, 1949).

TABLE 2

Wentworth's model with 2 pairs of genes applied to the Belgian Blue.

Le modèle de Wentworth à 2 paires de gènes, appliqué au Blanc-Bleu Belge.

\begin{tabular}{|c|c|c|c|}
\hline & $P P$ & $P p$ & $p p$ \\
\hline $\begin{array}{c}\boldsymbol{R} \boldsymbol{R} \ldots \ldots \ldots \ldots \ldots \\
\boldsymbol{R} r \ldots \ldots \ldots \ldots \ldots \\
r r \ldots \ldots \ldots \ldots \ldots\end{array}$ & $\begin{array}{l}\text { Blue } \\
\text { Blue } \\
\text { White }\end{array}$ & $\begin{array}{l}\text { Blue } \\
\text { Blue } \\
\text { White }\end{array}$ & $\begin{array}{l}\text { Black } \\
\text { Black } \\
\text { White }\end{array}$ \\
\hline
\end{tabular}

This hypothesis was devised by WENTWORTH to explain the exceptions incompatible with the single gene model. In opposition to the single gene model, it implies the existence of a blue that can breed true (genotype PPRR).

In a paper where population genetic theory was applied, probably for the first time, to solve a problem of animal genetics, WRIGHT (1917) showed that the model of WENTWORTH was wholly untenable and that Wilson's one-locus hypothesis was correct except for phenotypic overlaps and after allowing for Herd-Book errors. This approach will be illustrated below.

In 1933, IBSEN, to explain the exceptions to the one-factor hypothesis, such as the production of a high proportion of red progeny from a particular white bull 
and his son bred to red cows, postulated a recessive modifier $(\mathrm{rm})$ which changes genotypic roans to red. But for SHRODE \& LUSH (1947) « it appears that postulating $\mathrm{rm}$ raises more serious discrepancies than it explains, when one considers what frequency a gene like $r m$ must have in order to do that for which it is postulated ».

More recently, WrIGHT (1977) came back to this question and put to test, besides the "Wentworth» model, an additive genetic model with thresholds. Applied to the Belgian Blue, this additive model shows up as in table 3 . As does the previous one, this model implies that the blue phenotype could be fixed (genotypes $R_{1} R_{1} r_{2} r_{2}$ or $r_{1} r_{1} R_{2} R_{2}$ ).

\section{TABLE 3}

The additive model with thresholds.

Le modèle additif avec seuils.

\begin{tabular}{c|c|c}
\hline & Phenotypes \\
\hline White & Blue & Black \\
\hline$R_{1} R_{1} R_{2} R_{2}$ & $R_{1} R_{1} r_{2} r_{2}$ & $r_{1} r_{1} r_{2} r_{2}$ \\
$R_{1} r_{1} R_{2} R_{2}$ & $r_{1} r_{1} R_{2} R_{2}$ & $R_{1} r_{1} r_{2} r_{2}$ \\
$R_{1} R_{1} R_{2} r_{2}$ & $R_{1} r_{1} R_{2} r_{2}$ & $r_{1} r_{1} R_{2} r_{2}$ \\
At least three capital R's & Two capital R's & One capital R at most \\
\hline
\end{tabular}

\section{Results and discussion}

In the case of more than one pair of genes, the outcome of the mating types depends on gene frequencies.

\section{A. The Model with Interaction (Wentworth's model)}

Let $\mathrm{x}$ and $1-\mathrm{x}$ be the frequencies of alleles $\mathrm{R}$ and $\mathrm{r}$ and $\mathrm{y}$ and $1-\mathrm{y}$ be the frequencies of alleles $P$ and $p$, respectively.

In the case of panmictic equilibrium, the population has the genetic structure shown in table 4.

In our herd-book population, the frequencies of the phenotypes are approximately : 49 p. 100 (White) ; 42 p. 100 (Blue) ; 9 p. 100 (Black). As, in this model, the white individuals are of the genotype $\mathrm{rr}$, we may write :

$$
\begin{gathered}
(1-x)^{2}=0.49 \\
\text { and }: x=0.3 ; \text { and } 1-x=0.7
\end{gathered}
$$


TABLE 4

Genetic structure of the random mating population. Model with interaction.

Structure génétique de la population panmictique. Modèle avec interaction.

\begin{tabular}{|c|c|c|c|}
\hline & $\begin{array}{l}P P \\
\mathrm{y}^{2}\end{array}$ & $\begin{array}{c}P p \\
2 \mathrm{y}(1-\mathrm{y})\end{array}$ & $\begin{array}{c}p p \\
(1-y)^{2}\end{array}$ \\
\hline $\begin{array}{c}R R \\
\mathrm{x}^{2}\end{array}$ & $\begin{array}{c}R R P P \\
\mathrm{x}^{2} \mathrm{y}^{2} \\
\text { Blue }\end{array}$ & $\begin{array}{c}R R P p \\
\mathrm{x}^{2} \cdot 2 \mathrm{y}(1-\mathrm{y}) \\
\text { Blue } \\
\end{array}$ & $\begin{array}{c}R R p p \\
\mathrm{x}^{2}\left(1-\mathrm{y}^{2}\right. \\
\text { Black }\end{array}$ \\
\hline $\begin{array}{c}R r \\
2 \mathrm{x}(1-\mathrm{x})\end{array}$ & $\begin{array}{c}\operatorname{Rr} P P \\
2 \mathrm{x}(1-\mathrm{x}) \mathrm{y}^{2} \\
\text { Blue }\end{array}$ & $\begin{array}{c}R r P p \\
2 \mathrm{x}(1-\mathrm{x}) 2 \mathrm{y}(1-\mathrm{y}) \\
\text { Blue }\end{array}$ & $\begin{array}{c}R r p p \\
2 \mathrm{x}(1-\mathrm{x})(1-\mathrm{y})^{2} \\
\text { Black }\end{array}$ \\
\hline$(1-x)^{2}$ & $\begin{array}{c}\quad r r P P \\
(1-\mathrm{x})^{2} \cdot \mathrm{y}^{2} \\
\text { White }\end{array}$ & $\begin{array}{c}r r P p \\
(1-\mathrm{x})^{2} \cdot 2 \mathrm{y}(1-\mathrm{y}) \\
\text { White }\end{array}$ & $\begin{array}{c}\operatorname{rrpp} \\
(1-\mathrm{x})^{2}(1-\mathrm{y})^{2} \\
\text { White }\end{array}$ \\
\hline
\end{tabular}

On the other hand, under Wentworth's model the proportion of black individuals among the «non-whites» is given by :

$$
\begin{aligned}
& \frac{x^{2}(1-y)^{2}+2 x(1-x)(1-y)^{2}}{1-(1-x)^{2}} \\
& =(1-y)^{2}
\end{aligned}
$$

Therefore, the value of 0.58 for $y$ and of 0.42 for $1-y$. The gene frequencies being determined, it was possible to calculate what was expected from each mating. The results are given in table 5 .

If the expected results according to the single gene model are identical whatever the breed considered, it is no longer true with the epistatic model where the expectations depend on gene frequencies.

From table 5, it appears that the matings White $\times$ Black and Blue $\times$ Blue are expected to give proportions of the different colours which are totally incompatible with the observations reported in table 1 . The chi-squares with 2 degrees of freedom are respectively equal to : 100.37 and 374.7 .

The reader will notice that, according to the epistatic model, the same proportion of whites is expected from the matings White $\times$ Blue and White $\times$ Black. The same is true for the matings Blue $\times$ Blue, Blue $\times$ Black and Black $\times$ Black. 
TABLE 5

The proportions of the different phenotypes expected from each of the 6 possible parental pairs. Model with interaction fitted to the Belgian breed.

Les proportions attendues des différents phénotypes pour chacune des 6 paires parentales possibles. Modèle avec interaction ajusté à la race belge.

\begin{tabular}{|c|c|c|c|}
\hline \multirow{3}{*}{$\begin{array}{c}\text { Parental pairs } \\
\text { White } \\
\times \\
\text { White }\end{array}$} & \multicolumn{3}{|c|}{ Offspring } \\
\hline & White & Blue & Black \\
\hline & $\begin{array}{c}100 \% \\
(100 \%)\end{array}$ & - & - \\
\hline $\begin{array}{c}\text { White } \\
\times \\
\text { Blue }\end{array}$ & $\begin{array}{l}41.18 \% \\
(22.7 \%)\end{array}$ & $\begin{array}{l}51.51 \% \\
(53.9 \%)\end{array}$ & $\begin{array}{r}7.31 \% \\
(23.4 \%)\end{array}$ \\
\hline $\begin{array}{l}\text { White } \\
\times \\
\text { Black }\end{array}$ & $\begin{array}{c}41.18 \% \\
(22.7 \%)\end{array}$ & $\begin{array}{l}34.11 \% \\
(21.5 \%)\end{array}$ & $\begin{array}{c}24.71 \% \\
(55.8 \%)\end{array}$ \\
\hline $\begin{array}{c}\text { Blue } \\
\times \\
\text { Blue }\end{array}$ & $\begin{array}{l}16.95 \% \\
(5.1 \%)\end{array}$ & $\begin{array}{c}75.78 \% \\
(78.2 \%)\end{array}$ & $\begin{array}{r}7.27 \% \\
(16.7 \%)\end{array}$ \\
\hline $\begin{array}{c}\text { Blue } \\
\times \\
\text { Black }\end{array}$ & $\begin{array}{l}16.95 \% \\
(5.1 \%)\end{array}$ & $\begin{array}{l}58.48 \% \\
(55.1 \%)\end{array}$ & $\begin{array}{l}24.57 \% \\
(39.8 \%)\end{array}$ \\
\hline $\begin{array}{c}\text { Black } \\
\times \\
\text { Black }\end{array}$ & $\begin{array}{l}16.95 \% \\
(5.1 \%)\end{array}$ & - & $\begin{array}{l}83.05 \% \\
(84.09 \%)\end{array}$ \\
\hline
\end{tabular}

In parentheses, the proportions calculated by WRIGHT (1977) for the Shorthorn breed.

B. The additive model with thresholds

Let the gene frequencies be $x$ and $1-x$ for alleles $R_{1}$ and $r_{1} ; y$ and $1-y$ for alleles $R_{2}$ and $r_{2}$. If the population is panmictic, the population has the genetic structure shown in table 6.

The proportions of the 3 phenotypes in the population are :

White : $\quad x^{2} y^{2}+2 x^{2} y(1-y)+2 x(1-x) y^{2}=0.49$

Blue : $x^{2}(1-y)^{2}+4 x y(1-x)(1-y)+(1-x)^{2} y^{2}=0.42$

Black : $(1-x)^{2}(1-y)^{2}+2 x(1-x)(1-y)^{2}+2(1-x)^{2} y(1-y)=0.09$

By iteration, the following solutions are obtained :

$$
\begin{array}{ll}
x=0.892\left(R_{1}\right) & (1-x)=0.108\left(r_{1}\right) \\
y=0.356\left(R_{2}\right) & (1-y)=0.644\left(r_{2}\right)
\end{array}
$$


TABLE 6

Genetic structure of the random mating population. Additive model with thresholds.

Structure génétique de la population panmictique. Modèle additif avec seuils.

\begin{tabular}{|c|c|c|c|}
\hline & $\begin{array}{c}R_{2} R_{9} \\
\mathrm{y}^{2}\end{array}$ & $\underset{2 \mathrm{y}(1-\mathrm{g})}{R_{2} r_{2}}$ & $\left(1-\frac{r_{2} r_{2}}{y}\right)^{2}$ \\
\hline \multirow[t]{2}{*}{$\begin{array}{l}R_{1} R_{t} \\
\mathrm{x}^{2}\end{array}$} & $\begin{array}{l}R_{1} R_{1} R_{2} R_{2} \\
\quad \mathrm{x}^{2} \mathrm{y}^{2}\end{array}$ & $\begin{array}{c}R_{1} R_{1} R_{2} r_{2} \\
2 \mathrm{x}^{2} \mathrm{y}(1-\mathrm{y})\end{array}$ & $\begin{array}{c}R_{1} R_{1} r_{2} r_{2} \\
\mathrm{x}^{2}(1-\mathrm{y})^{2}\end{array}$ \\
\hline & White & White & Blue \\
\hline \multirow[t]{2}{*}{$\begin{array}{c}R_{1} r_{1} \\
2 \mathrm{x}(1-\mathrm{x})\end{array}$} & $\begin{array}{c}R_{1} r_{1} R_{2} R_{2} \\
2 \mathrm{x}(1-\mathrm{x}) \mathrm{y}^{2}\end{array}$ & $\begin{array}{c}R_{1} r_{1} R_{2} r_{2} \\
4 \mathrm{xy}(1-\mathrm{x})(1-\mathrm{y})\end{array}$ & $\begin{array}{c}R_{t} r_{1} r_{2} r_{2} \\
2 \mathrm{x}(1-\mathrm{x})(1-\mathrm{y})^{2}\end{array}$ \\
\hline & White & Blue & Black \\
\hline \multirow[t]{2}{*}{$\begin{array}{c}r_{1} r_{1} \\
(1-\mathrm{x})^{2}\end{array}$} & $\begin{array}{c}r_{1} r_{1} R_{2} R_{2} \\
(1-x)^{2} y^{2}\end{array}$ & $\begin{array}{c}r_{1} r_{1} R_{2} r_{2} \\
2(1-\mathrm{x})^{2}(\mathrm{y}(1-\mathrm{y})\end{array}$ & $\begin{array}{c}r_{1} r_{1} r_{2} r_{2} \\
(1-x)^{2}(1-y)^{2}\end{array}$ \\
\hline & Blue & Black & Black \\
\hline
\end{tabular}

Once the gene frequencies are known, the expectations for cach mating type are calculated (tabl. 7).

As for the previous model, there is a strong incompatibility between the observed and the expected results for the matings: White $\times$ Black and Blue $\times$ Blue. (The corresponding $\mathrm{X}_{2}^{2}$ amount to : 88.39 and 463.20).

\section{The single gene model}

Compared with the expectations derived from the models with 2 pairs of genes, the single gene model, with genotypes $R R$ for all-white ; $R r+$ for blue and $r^{+} r^{+}$for black is in a better agreement with the observations than any other model since the proportions of the 3 phenotypes observed in the mating blue $\times$ blue agree only with the single gene hypothesis.

The explanation of the discrepancies is to be found in errors of recording and in the overlapping of phenotypes due to the segregation of minor factors : dark blue could be recorded as black, faint blue or blue with extended white-spotting as white.

Therefore, we feel compelled to apply to the Belgian Blue the conclusion reached by WRIGHT (1917) when he writes that the observed results for the different matings " can hardly be accounted for on any theory of inheritance other than a single main mendelian factor without dominance $\gg$. 


\section{TABLE 7}

The proportions of the different phenotypes expected from each of the 6 possible parental pairs. Additive model with thresholds fitted to the Belgian breed.

Les proportions attendues des différents phénotypes pour chacune des 6 paires parentales possibles. Modèle additif avec seuils ajusté à la race belge.

\begin{tabular}{c|c|c|c}
\hline \hline \multirow{2}{*}{ Parental pairs } & & Offspring & Black \\
\cline { 2 - 4 } $\begin{array}{c}\text { White } \\
\times \\
\text { White }\end{array}$ & 0.842 & Blue & - \\
\hline $\begin{array}{c}\text { White } \\
\times \\
\text { Blue }\end{array}$ & $(0.774)$ & 0.158 & - \\
\hline $\begin{array}{c}\text { White } \\
\times \\
\text { Black }\end{array}$ & 0.592 & $(0.226)$ & 0.021 \\
\hline $\begin{array}{c}\text { Blue } \\
\times \\
\text { Blue }\end{array}$ & $(0.522)$ & 0.387 & $(0.021)$ \\
\hline $\begin{array}{c}\text { Blue } \\
\times \\
\text { Black }\end{array}$ & 0.318 & $(0.456)$ & 0.188 \\
\hline $\begin{array}{c}\text { Black } \\
\times \\
\text { Black }\end{array}$ & $(0.211)$ & 0.494 & $(0.284)$ \\
\hline & 0.097 & $(0.505)$ & 0.097 \\
\hline & $(0.084)$ & 0.806 & $(0.084)$ \\
\hline & 0.028 & $(0.832)$ & 0.476 \\
\hline & $(0.018)$ & 0.496 & $(0.588)$ \\
\hline & - & $(0.394)$ & 0.722 \\
\hline & 0.277 & $(0.838)$ \\
\hline
\end{tabular}

In parentheses, the proportions calculated by WRIGHT (1977) for the Shorthorn breed.

\section{The progeny of A.I. sires}

With the gene frequencies arrived at previously, it is possible to calculate, for each genetic model, the expectations concerning the composition of the progeny of sires mated at random in the population. The results are given in table 8 .

On the other hand, the proportions of the different colour types actually observed in the progeny (colour phenotypes of the dams unknown, recording with lower accuracy than in the Herd-Book data) of 137 A.I. sires used in commercial herds are given in table 9. 
TABLE 8

The expected composition of the progeny of A.I. sires, according to the genetic model.

La composition attendue de la descendance des taureaux I.A., selon le modèle génétique.

\begin{tabular}{|c|c|c|c|c|}
\hline & \multirow{2}{*}{$\begin{array}{l}\text { Coat colour } \\
\text { of the sire }\end{array}$} & \multicolumn{3}{|c|}{ Offspring } \\
\hline & & White & Blue & Black \\
\hline \multicolumn{5}{|l|}{ White } \\
\hline & 1. $\ldots \ldots$ & 0.700 & 0.300 & - \\
\hline & 2. $\ldots$ & 0.700 & 0.247 & 0.053 \\
\hline & $\ldots \ldots \ldots$ & 0.687 & 0.285 & 0.028 \\
\hline \multicolumn{5}{|l|}{ Blue } \\
\hline & 1. $\ldots$ & 0.350 & 0.500 & 0.150 \\
\hline & 2. $\quad \ldots \ldots \ldots \ldots \ldots$ & 0.290 & 0.620 & 0.090 \\
\hline & 3. $\quad \ldots \ldots \ldots \ldots \ldots$ & 0.318 & 0.612 & 0.070 \\
\hline \multicolumn{5}{|l|}{ Black } \\
\hline & $1 . \quad \ldots \ldots \ldots \ldots \ldots$ & - & 0.700 & 0.300 \\
\hline & 2. $\ldots$ & 0.290 & 0.410 & 0.300 \\
\hline & 3. $\ldots$ & 0.150 & 0.457 & 0.290 \\
\hline
\end{tabular}

Genetic model : 1. Single gene; 2. Epistatic model ; 3. Additive model.

TABLE 9

The proportions, with standard deviation and range, of the 3 colour types in the progeny of A.I. sires.

(Progeny-test results from 1978 to 1983).

Les proportions, avec leur erreur standard et l'étendue, des 3 phénotypes de couleur dans la descendance des taureaux I.A. (Résultats de testage de 1978 à 1983).

\begin{tabular}{c|c|c|c}
\hline Sires & \multicolumn{3}{|c}{ Offspring } \\
\cline { 2 - 4 } & White & Blue & Black \\
\cline { 2 - 4 }$(\mathrm{n}=70)$ & $\begin{array}{c}50.87(5.34) \\
(35.4-61.0)\end{array}$ & $\begin{array}{c}44.63(5.21) \\
(31.6-57.8)\end{array}$ & $\begin{array}{c}4.50(2.23) \\
(1.0-11.5)\end{array}$ \\
\hline $\begin{array}{c}\text { Blue } \\
(\mathrm{n}=65)\end{array}$ & $\begin{array}{c}35.22(4.49) \\
(22.2-47.0)\end{array}$ & $\begin{array}{c}46.01(4.39) \\
(33.3-55.8)\end{array}$ & $\begin{array}{c}18.77(3.58) \\
(11.4-29.3)\end{array}$ \\
\hline $\begin{array}{c}\text { Black } \\
(\mathrm{n}=2)\end{array}$ & $\begin{array}{c}9.40(5.16) \\
(5.4-12.7)\end{array}$ & $\begin{array}{c}59.43(15.84) \\
(46.0-68.4)\end{array}$ & $\begin{array}{c}31.17(6.93) \\
(25.1-34.9)\end{array}$ \\
\hline \hline
\end{tabular}


These 137 A.I. sires are subdivided into 70 whites with 258 calves per sire, 65 blues with 231 calves per sire, 2 blacks with 205 calves per sire. results :

The proportions expected from the 2 genes models disagree with the observed

1) for the difference in the proportions of blacks between white sires and blue sires ;

2) for the difference in the proportions of blues between blue sires and black sires, the proportion of blues expected from blue sires being higher than the proportion expected from black sires ;

3) for the difference in the proportions of whites between blue sires and black sires, the black genotype Rrpp giving as many as 35 p. 100 whites (tabl. 10).

TABLE 10

Proportions of the colour phenotypes in the offspring of each genotype (random mating). Epistatic model (gene frequencies given above).

Proportions des phénotypes de couleur dans la descendance de chaque génotype (panmixie). Modèle épistatique (fréquences géniques données plus haut).

\begin{tabular}{|c|c|c|c|}
\hline \multirow{2}{*}{ Genotypes (Frequencies) } & \multicolumn{3}{|c|}{ Offspring } \\
\hline & White $(\%)$ & Blue $(\%)$ & Black $(\%)$ \\
\hline \multicolumn{4}{|l|}{ White } \\
\hline$r r P P \quad(33.6 \%) \ldots \ldots \ldots$ & 70.0 & 30.0 & - \\
\hline$r r P p \quad(48.7 \%) \quad \ldots \ldots \ldots$ & 70.0 & 23.7 & 6.3 \\
\hline $\operatorname{rrpp} \quad(17.7 \%) \ldots \ldots \ldots$ & 70.0 & 17.4 & 12.6 \\
\hline \multicolumn{4}{|l|}{ Blue } \\
\hline $\operatorname{RRPP} \quad(7.2 \%) \ldots$ & - & 100.0 & - \\
\hline$R R P p(10.4 \%) \ldots \ldots \ldots$ & - & 79.0 & 21.0 \\
\hline $\operatorname{RrPP}(33.6 \%) \ldots \ldots \ldots$ & 35.0 & 65.0 & - \\
\hline $\operatorname{RrPp} \quad(48.7 \%) \quad \ldots \ldots \ldots$ & 35.0 & 51.3 & 13.6 \\
\hline \multicolumn{4}{|l|}{ Black } \\
\hline$R R p p \quad(17.6 \%) \quad \ldots \ldots \ldots$ & - & 58.0 & 42.0 \\
\hline $\operatorname{Rrpp} \quad(82.4 \%) \quad \ldots \ldots \ldots$ & 35.0 & 37.7 & 27.3 \\
\hline
\end{tabular}

On the other hand, considering the individual genotypes, the 3 genetic models have their own implications.

In the epistatic model (tabl. 10), within the blue phenotype, genotypes RRPP and $R R P p$ are expected to give zero percent whites, the genotype $R R P P$ to give 100 p. 100 blues but genotypes RRPP and RrPP would not beget any black. 
In the additive model (tabl. 11) a white genotype $\left(R_{1} R_{1} R_{2} R_{2}\right)$ would give as many as 93 p. 100 whites and as already shown, blue genotypes $\left(R_{1} R_{1} r_{2} r_{2}\right.$ and $r_{1} r_{1} R_{2} R_{2}$ ) would give a higher proportion of blues (around $60 \mathrm{p} .100$ ) than any black genotype. These implications are incompatible with the observations reported in table 9. Besides the ranges presented in table 9, a series of figures depict the distribution of the 137 A.I. sires, regarding the proportion of blacks (fig. 1), the proportion of whites (fig. 2). Figure 3 shows the joint distribution of the sires for these 2 proportions.

TABLE 11

Proportions of the colour phenotypes in the offspring of each genotype (random mating). Additive model (gene frequencies given above).

Proportions des phénotypes de couleur dans la descendance de chaque génotype (panmixie). Modèle additif (fréquences géniques données plus haut).

\begin{tabular}{|c|c|c|c|c|}
\hline \multirow{2}{*}{\multicolumn{2}{|c|}{ Genotypes (Frequencies) }} & \multicolumn{3}{|c|}{ Offspring } \\
\hline & & White $(\%)$ & Blue $(\%)$ & Black $(\%)$ \\
\hline \multicolumn{5}{|l|}{ White } \\
\hline$R_{1} R_{1} R_{2} R_{2}$ & $(20.6 \%)$ & 93.0 & 7.0 & 一 \\
\hline$R_{1} R_{1} R_{2} r_{2}$ & $(74.4 \%)$ & 62.4 & 34.1 & 3.5 \\
\hline$R_{1} r_{1} R_{2} R_{2}$ & $(5.0 \%)$ & 62.4 & 34.1 & 3.5 \\
\hline \multicolumn{5}{|l|}{ Blue } \\
\hline$R_{1} R_{1} r_{2} r_{2}$ & $(78.6 \%)$ & 31.7 & 61.3 & 7.0 \\
\hline$r_{1} r_{1} R_{2} R_{2}$ & $(21.0 \%) \ldots$ & 31.7 & 61.3 & 7.0 \\
\hline$R_{1} r_{1} R_{2} r_{2}$ & $(0.3 \%)$ & 39.1 & 40.3 & 20.5 \\
\hline \multicolumn{5}{|l|}{ Black } \\
\hline$R_{1} r_{1} r_{2} r_{2}$ & $(88.7 \%)$ & 15.9 & 46.5 & 37.6 \\
\hline$r_{1} r_{1} R_{2} r_{2}$ & $(5.9 \%)$ & 15.9 & 46.5 & 37.6 \\
\hline$r_{1} r_{1} r_{2} r_{2}$ & $(5.4 \%)$ & - & 31.7 & 68.2 \\
\hline
\end{tabular}

It is obvious from these illustrations that the white, blue and black sires belong to 3 distinct populations. The overlapping is very limited in contrast to the expectations from the epistatic model, which implies an important overlapping for the white sires and the blue sires regarding the proportions of black and for the blue sires and the black sires regarding the proportions of whites. The distances observed between the observed means amount to 3 times the standard deviation, at least. No doubt, a major pair of alleles $\left(R, r^{+}\right)$is segregating within this population.

Around each of the main genotypes $\left(R R, R^{+}+r^{+} r^{+}\right)$an important variation does exist, which is caused :

1) by other genes for which the sires differ (single genes such as the dominant genes for the colour-sided pattern and the white face, modifiers of the recessive whitespotting, of the intensity of blue; 


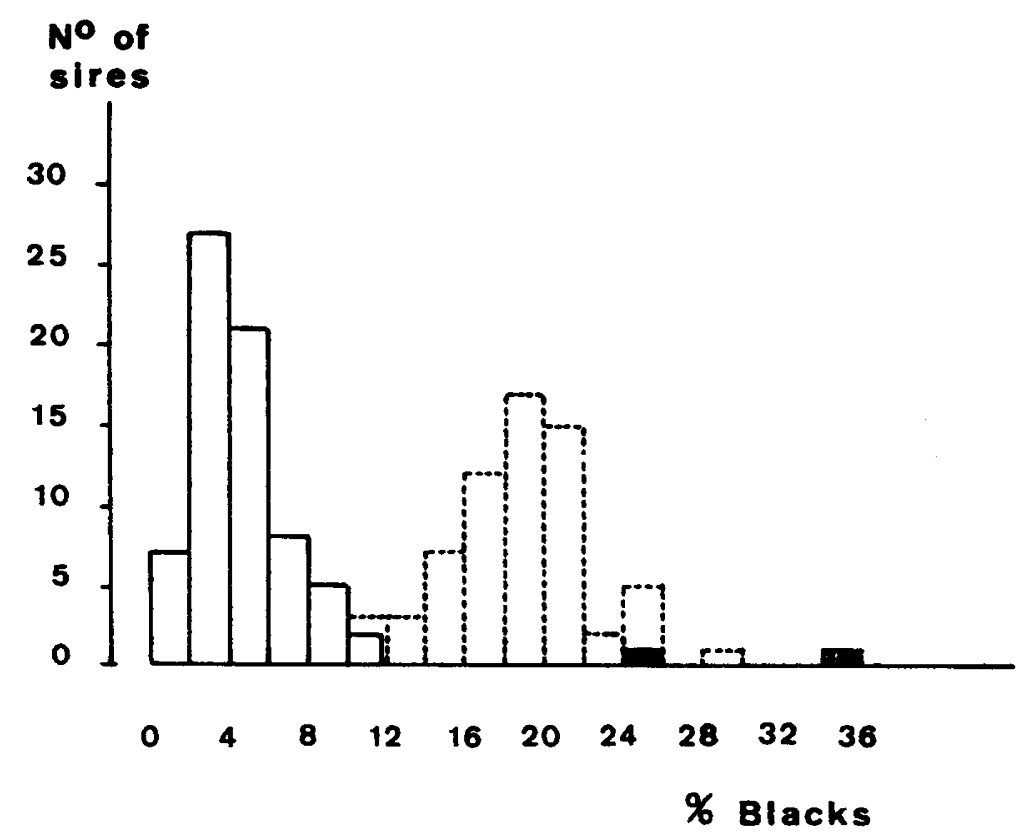

FIG. 1

Distribution of the proportion of blacks in the progeny of 137 A.I. sires. Distribution de la proportion de noirs dans la descendance de 137 taureaux I.A.

- White sires.

-..- Blue sires.

- Black sires.

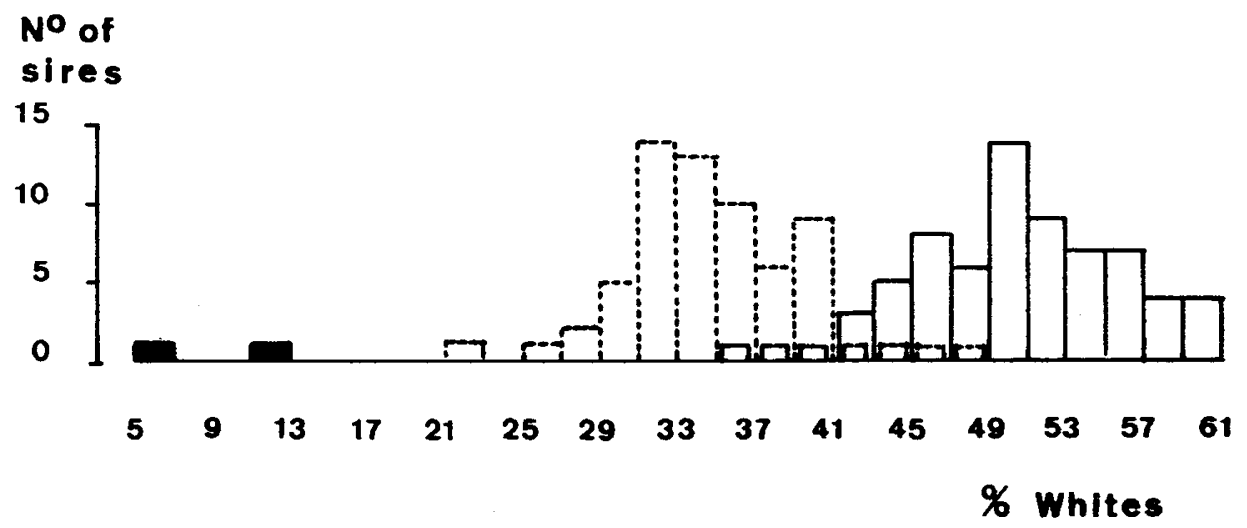

FIG. 2

Distribution of the proportion of whites in the progeny of 137 A.I. sires. Distribution de la proportion de blancs dans la descendance de 137 taureaux I.A. - White sires.

-... Blue sires.

a Black sires. 


\section{\% Blacks}
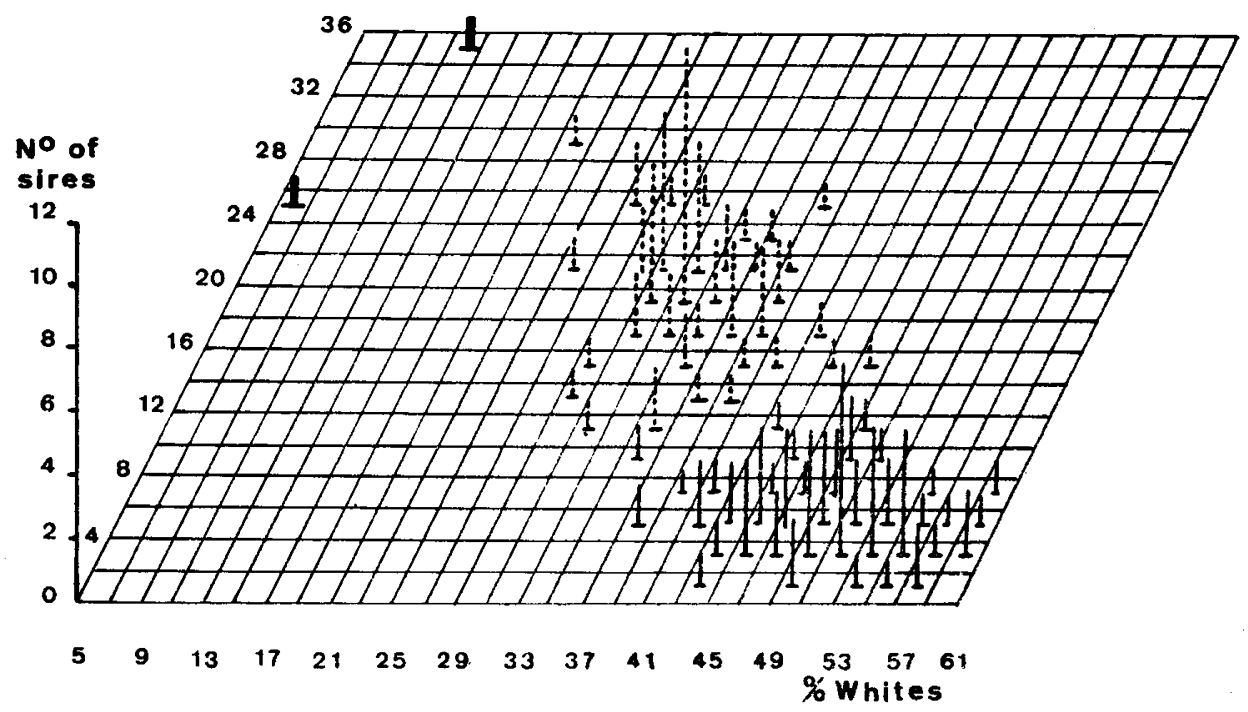

Fig. 3

Joint distribution of the proportions of blacks and whites in the progeny of 137 A.I. sires. Distribution conjointe des proportions de noirs et de blancs dans la descendance de 137 taureaux I.A.

White sires.

... Blue sires.

Black sires.

In white spotted breeds, there are all gradations from almost completely white to almost completely coloured. The heritability of this variation was estimated by BRIQUET \& LUSH (1947) and was found to be higher than 0.9. The association between pigmented body area was investigated by TREECE et al. (1956). They found that females had approximately 6 percentage units more pigmented area on the body than males and that the amount of pigment of the body was closely related with the amount of white on the head. Likewise, the extent of colouring in the colour-sided pattern shows a great variation due to modifying genes (HILDEMAN cited by RENDEL, 1959). But, as before, a fact remains : blacks are born from white sires and whites are born from black sires and to fit the single gene model to the data, one has to admit some amount of overlap of phenotypes, chiefly, that there are blacks and whites of genotypes $R r^{+}$. It is also the opinion expressed by WRIGHT (1977) when he notes that « roan certainly varies, almost from self-red to white and it is probable that there is actual overlap».

From time to time, the phenotype of an A.I. bull registered as white, has to be reconsidered on the basis of his progeny test results. In each case, a close examination reveals that in fact the phenotype is blue.

Let, $a, b$ and $c(a+b+c=1)$ be the proportions of individuals of genotype $R r+$ classified as white, blue and black respectively. Accordingly, if $\mathrm{p}$ and $1-\mathrm{p}$ are 
the frequencies of the alleles $R$ and $r^{+}$in the cow population bred to A.I. bulls, the distribution of their progeny in the 3 phenotypic classes is as shown in tabl. 12, for each type of sire.

\section{TABLE 12}

The expected distribution, in the 3 phenotypic classes, of the progeny of the 3 kinds of A.I. sires.

La distribution attendue, dans les 3 classes phénotypiques, de la descendance des 3 types de taureaux I.A.

\begin{tabular}{|c|c|c|c|}
\hline \multirow{2}{*}{$\begin{array}{l}\text { Genotype } \\
\text { of the sire }\end{array}$} & \multicolumn{3}{|c|}{ Phenotypic classes } \\
\hline & White & Blue & Black \\
\hline$R R \ldots$ & $p+(1-p) \cdot a$ & $(1-p) \cdot b$ & $(1-p) \cdot c$ \\
\hline$R r+$ & $1 / 2 p+1 / 2 \cdot a$ & $1 / 2 \cdot b$ & $1 / 2 c+1 / 2(1-p)$ \\
\hline$r+r+\ldots \ldots$ & p.a & p.b & $p c+(1-p)$ \\
\hline
\end{tabular}

Maximum likelihood estimates of the parameters, p, a, b were obtained for each type of sire, separately, the observed proportions being taken from table 9. These estimates and the ensuing proportions are given in table 13 as well as the observed proportions taken from table 9. A very close fit is reached if allowance is made for overlaps of phenotypes.

TABLE 13

The distribution, in the 3 phenotypic classes, of the progeny of the 3 kinds of A.I. sires.

La distribution, dans les 3 classes phénotypiques, de la descendance des 3 types de taureaux I.A.

\begin{tabular}{|c|c|c|c|c|c|c|c|}
\hline & \multirow{2}{*}{ Sires } & \multicolumn{3}{|c|}{ Phenotypic classes } & \multicolumn{3}{|c|}{ Parameters } \\
\hline & & White & Blue & Black & p & a & b \\
\hline$R R$ & $\begin{array}{l}\text { Exp. } \\
\text { Obs. }\end{array}$ & $\begin{array}{l}51.00 \\
50.87\end{array}$ & $\begin{array}{l}44.50 \\
44.63\end{array}$ & $\begin{array}{l}4.50 \\
4.50\end{array}$ & 0.50 & 0.02 & 0.89 \\
\hline$R r+$ & $\begin{array}{l}\text { Exp. } \\
\text { Obs. }\end{array}$ & $\begin{array}{l}35.00 \\
35.22\end{array}$ & $\begin{array}{l}46.00 \\
46.01\end{array}$ & $\begin{array}{l}19.00 \\
18.77\end{array}$ & 0.62 & 0.08 & 0.92 \\
\hline$r+r+$ & $\begin{array}{l}\text { Exp. } \\
\text { Obs. }\end{array}$ & $\begin{array}{l}6.57 \\
9.40\end{array}$ & $\begin{array}{l}62.05 \\
59.43\end{array}$ & $\begin{array}{l}31.38 \\
31.17\end{array}$ & 0.73 & 0.09 & 0.85 \\
\hline
\end{tabular}


The estimate of the proportion of $\mathrm{Rr}^{+}$genotypes recorded as blue ranges from 0.85 to 0.92 . Furthermore, the estimates of $p$ suggest that there is some choice by the breeders regarding the colour of the sire, e.g., white bulls are used more often on coloured cows (blue or black) while black bulls are more often used on white cows in order to limit the production of undesirable black animals.

\section{E. The E. locus}

In the Belgian White and Blue breed, besides the segregation at the $R$ locus, there is also segregation at the $E$ locus (allele $E^{d}$ : normal extension of black; allele $e$ : restriction of black : red. (For reviews on colour inheritance in cattle, see LAUVERGNe, 1966 ; SEARLE, 1968).

Accordingly, the phenotypes are :

$R R E^{d-}$ (all-white, blue ears); RRee (all-white, red ears);

$R r+E^{d-}$ (blue) $; R r+e e$ (roan); $r+r+E^{d-}$ (black); $r+r+e e$ (red).

The Shorthorn breed is homozygous ee.

Animals with red hairs are not registered in the Belgian Herd-Book; so, A.I. bulls can be, at most, heterozygous $E e$ although we discovered, some years ago, an A.I. bull registered as white which was shown to be of genotype RRee from progenytest results ; his red hairs were so sparse that they had escaped notice at the time of registration (HANSET, $1959 \mathrm{~b}, 1965$ ).

On a total of 189 A.I. sires (104 whites; 83 blues ; 2 blacks), 10 bulls ( 7 were white and 3 were blue) were shown to be heterozygous $E e$ through their offspring, the proportion of calves with red hairs ranging from 4 p. 100 to 10 p. 100.

Received December 3, 1984.

Accepted March 27, 1985.

\section{Acknowledgements}

The author wishes to dedicate this paper to Dr Sewall WRIGHT, intellectual and practically-oriented giant in the development of Population Genetics.

Drs C. Michaux, P. Leroy and C. Schirvel are thanked for their kind collaboration and Mr A. Breuls DE TIECKEN for his skilful assistance in typing the manuscript and drawing the figures.

\section{References}

Barrington A., Pearson K., 1906. On the inheritance of coat colour in cattle. Biometrica, 4, 427-464.

Briquet R., LuSH J.L., 1947. Heritability of amount of spotting in Holstein Friesian cattle. J. Hered., 31, 253-256.

Darlington C.D., Mather K., 1949. The Elements of Genetics. 446 pp., Allen and Unwin, London. 
Hanset R., 1959 a. L'hérédité des robes dans la race bleu-blanc de Moyenne et Haute Belgique. II. Les résultats de divers types d'accouplement chez les animaux inscrits aux Syndicats d'élevage. Ann. Med. Vet., 103, 245-255.

HANSET R., 1959 b. L'hérédité des robes dans la race bleu-blanc de Moyenne et Haute Belgique. III. Les génotypes de robe de quelques taureaux I.A. Ann. Med. Vet., 103, 299-309.

HANSET R., 1965. Recherches sur la White Heifer Disease et son déterminisme génétique. Comptes rendus de Recherches, 177 pp., I.R.S.I.A., Bruxelles.

IBSEN H.L., 1933. Cattle inheritance. Genetics, 18, 441-482.

LAUVERGNe J.J., 1966. Génétique de la couleur du pelage des bovins domestiques. Biblio. Genet., 20, 1-68.

Rendel J., 1959. Farbe und Zeichnung. In Hammond J., Johansson I., Haring F. (ed.), Haustiergenetik, 105-141, Paul Parey, Hambourg.

Rendel J.M., 1952. White Heifer disease in a herd of dairy Shorthorns. J. Genet., 51, 89-94.

Searle A.G., 1968. Comparative Genetics of Coat Colour in Mammals, 308 pp., Logos press, London.

Smith A.D.B. 1925. A study of the inheritance of certain color characters in the Shorthorn breed of cattle. J. Hered., 16, 73-84.

Shrode R.R., Lush J.L., 1947. The Genetics of Cattle. In : Demerec M. (ed.), Advances in Genetics, vol. 1, 210-261 Academic Press, New York.

Treece J.M., Gilmore L.O., Laird R., FechHeimer N.S., 1956. The amount of pigmented body area in spotted cattle as associated with head pattern and as influenced by sex. J. Dairy Sci., 39, 933-934.

Wentworth E.N., 1913. Color in Shorthorn cattle. Amer. Breeders Mag., 4, 202-208 (cited by Wright 1917).

WILson J., 1908. Mendelian characters among Shorthorn cattle. Sci. Proc. Roy. Dublin Soc., 11, 317-324.

Wright S., 1917. Color inheritance in mammals : cattle. J. Hered., 8, 521-527.

Wright S., 1977. Evolution and the Genetics of Populations. Experimental results and evolutionary deductions. Vol. 3, 613 pp. The University Chicago Press. 